\section{SCIENTIFIC CARE FOR THE ARTS}

Recent Advances in Conservation

Contributions to the I.I.C. Rome Conference, 1961. Edited by G. Thomson. Pp. xv +224 . (London: Butterworths, 1963.) $105 s$.

HIS handsome volume is the outcome of a conference held in Rome in 1961, and contains forty-seven papers dealing with almost every aspect of the conservation of art treasures. While it is true that there have been assemblies of experts on various occasions before, this is the first time in which the whole field has been covered, not only technically, but by representatives from all over the world. This wide spread is itself of significance, because there are signs that a new applied science is beginning to take shape, namely, that of museum climat. ology, or the study of the meteorological conditions under which precious material must be kept in divers countries. Here, knowledge of local circumstances and an appreciation of administrative problems are almost as important as a grasp of thermodynamic principles.

After such an appropriate beginning follow contributions dealing with methods of analysis, fungicides, cleaning methods, metallic objects, Italian methods of fresco transfer, consolidation of fragile objects, glass, wood panels, new picture varnishes, textiles and tapestries, education and training. A notable omission from the well-arranged and copious references is any mention of the elegant researches of Graham on diffusion through thin films (using interferometric techniques), and the associated question of the activity of mixed solvents, together with the behaviour of plasticizers. The text is fully illustrated, with a double frontispiece in colour.

It would serve little purpose to follow the authors through the minutiae of their labours; this book should find a place in every museum or gallery library wherein the task of custodianship is taken seriously. Without exception, the participants in this international gathering were people grappling with the most complex situations in their various countries, and, as the President remarks in a brief foreword, they bear the responsibility for safeguarding the cultural heritage of twenty-five centuries. Regarded in this light, such a discussion-at specialist level-assumes the character of an international event, which does credit to "I.I.C.", as it is affectionately called, and to the faith and generosity of the Calouste Gulbenkian Foundation, Lisbon, which provided essential financial support. The Editor, too, has carried a heavy load, and fully merits, as he will surely receive, many congratulations on the result of months of careful work and supervision. It is probable that from time to time conservators will come together to exchange views, and to lay down agreed programmes of investigation into ad hoc topics, but that will not prevent the present compilation from remaining the basic source of information for many a year.

The official languages of the conference were English and French, and these are reflected in the papers before us. There is an odd misprint in the caption on page 19 , where 'Neuvres' should presumably be 'Oeuvres'. The more purely scientific aspect of the subject is maintained at a high standard, although there is one slightly naïve remark on p. 7, where we are exhorted "to know what light really is". Indeed, from Newton to Einstein at least, we should be happier and wiser if we knew the answer.

Towards the end come some valuable comments on the subject of organized courses of instruction for would-be entrants into the field. The difficulty of obtaining degree status is probably not merely a matter of the additional year (important as that is), but the natural hesitancy of university authorities to accept conservation in general as an academic discipline. It would seem likely that the most hopeful approach might be by stressing the epistemological connexion between art-history and the develop- ment of technique. Care of what is, by hypothesis, unique is much more than mere 'doctoring': it is a major contribution to civilization, and needs to be taught as such. If there is any doubt of this, the distinction and integrity of these pages speak for themselves.

\section{AN AID TO SORGHUM GROWING}

Diseases of Sorghum Sudan Grass and Broom Corn By Dr. S. A. J. Tarr. Pp. $x+380$ (43 figures). (Kew, Surrey: The Commonwealth Mycologieal Institute, 1962.) $60 s$.

7 HE post-war years have seen the emergence of many previously underdeveloped countries into political independence, and the means by which they can be brought into some form of economic stability are, we hope, the earnest concern of all. Not least of the problems in tropical and sub-tropical territories is the raising of the nutritional level of the indigenous populations and this, in effect, means the greatly increased production of crops suited to the areas in question. Sorghums, because of their special qualities, have a large contribution to make in this connexion and it is fitting and timely, therefore, that the Commonwealth Mycological Institute should publish the present volume on the diseases of sorghum, sudan grass, and broom corn. Dr. Tarr, the author, was formerly chief plant pathologist to the Republic of the Sudan and is obviously qualified to speak with authority on the diseases of a group of plants worthy of more recognition than it has had in scientific literature up to the present.

Dr. Tarr starts with a brief treatment of the morphology and taxonomy of the three species, Sorghum vulgare, $S$. sudanense and S. bicolor var. technicum, and some discussion of the genus as a whole. An informative section is included on sorghum poisoning of livestock in which the literature on this subject is summarized. The main portion of the book divides the diseases into those affecting the seed and seedling, the root and stalk, the foliage and the inflorescence and developing grain. The more important diseases, such as those due to Helminthosporium spp. and the smut fungi, are dealt with in considerable detail, and justifiably so. There would appear to be less noed for the amount of space devoted to seed treatments and some pruning of the literature included would have been an advantage here. In every case the pathogen. is fully described with the necessary diagnostic detail and this is one of the most valuable features of the book. An appendix listing fungi recordod on Sorghum but not included in the main text, since many of them are not specialized pathogens, is a model of what the presentation of information for pathologists should be and makes one wonder whether some of the longer passages in the foregoing chapters were really necessary.

Bacterial and virus diseases provide a minor, but important, section. The rapid rise in importance of grass and cereal virus diseases that we have witnessed in the past fifteen years may well be repeated in sorghums since the potential would appear to be there.

It may surprise some to note that, on occasion, more serious menaces to sorghum growing than the orthodox types of disease are higher plants of the parasitic genus Striga. A most interesting and instructive chapter is included on this subject.,

The book is well printed with useful plates and some boautiful drawings reproduced, for the most part, from originals by Dr. A. M. Saccas. A bibliography of more than 1,200 titles is included. Dr. Tarr is to be commended on the production of a work that is likely to be the authoritative text on this subject for a long time to come. He has certainly succeeded in his avowed purpose of providing a book to enable cultivators, agricultural officers, and pathologists to recognize and possibly control sorghum diseases.

J. H. Western 